\title{
Annealing Effect on the Structure and Optical Properties of CBD-ZnS Thin Films for Windscreen Coating
}

\author{
Raghad Y. Mohammed
}

check for updates

Citation: Mohammed, R.Y.

Annealing Effect on the Structure and Optical Properties of CBD-ZnS Thin Films for Windscreen Coating. Materials 2021, 14, 6748. https:// doi.org/10.3390/ma14226748

Academic Editors: Alexander N. Obraztsov and Mikhael Bechelany

Received: 24 September 2021 Accepted: 5 November 2021 Published: 9 November 2021

Publisher's Note: MDPI stays neutral with regard to jurisdictional claims in published maps and institutional affiliations.

Copyright: (C) 2021 by the author. Licensee MDPI, Basel, Switzerland. This article is an open access article distributed under the terms and conditions of the Creative Commons Attribution (CC BY) license (https:// creativecommons.org/licenses/by/ $4.0 /)$.
Department of Physics, College of Science, University of Duhok, Duhok 42001, Iraq; ssraghad@uod.ac

\begin{abstract}
Zinc sulfide ( $\mathrm{ZnS})$ thin films were prepared and synthesized by the chemical bath deposition (CBD) technique on microscopic glass substrates using stoichiometric amounts of the precursor materials $\left(\mathrm{ZnSO}_{4} \cdot 7 \mathrm{H}_{2} \mathrm{O}, \mathrm{NH}_{4} \mathrm{OH}\right.$, and $\left.\mathrm{CS}\left(\mathrm{NH}_{2}\right)_{2}\right)$. Structural, morphological, compositional, and optical characterization of the films were studied. The obtained thin films were found to exhibit polycrystalline possessions. The effect of annealing temperature on the crystallographic structure and optical bandgap of $\mathrm{ZnS}$ thin films were both examined. The grain size and unit cell volume were both found to be increased. In addition, the strain, dislocation density, and the number of crystallites were found to be decreased with annealing temperature at $300^{\circ} \mathrm{C}$. However, the annealed sample was perceived to have more $\mathrm{Zn}$ content than $\mathrm{S}$. The optical characterization reveals that the transmittance was around $76 \%$ of the as-deposited thin film and had been decreased to $~ 50 \%$ with the increasing of the annealing temperature. At the same time, the bandgap energy of the as-deposited film was $3.98 \mathrm{eV}$ and was found to be decreased to $3.93 \mathrm{eV}$ after annealing.
\end{abstract}

Keywords: ZnS; chemical bath deposition; annealing; energy gap

\section{Introduction}

$\mathrm{ZnS}$ is an II-VI compound semiconductor that is found in two forms: a cubic form (c-ZnS) and hexagonal form (h-ZnS). At normal conditions of temperature and pressure, it crystallites in a zinc-blended structure [1]. Recently ZnS has been studied extensively because of its wide applications in optoelectronic devices due to direct broad bandgap 3.6 3.8 eV in the bulk and considerable exciton binding energy [2-4]. The broad bandgap of $\mathrm{ZnS}$ makes it a very significant material for UV-LED [5], flat panel displays [6], windows for solar cells, and sensors [7].

$\mathrm{ZnS}$ thin films can be synthesized by several techniques such as Chemical Vapor Deposition (PVD) [8], spray pyrolysis [9], RF sputtering [10], Chemical Bath Deposition (CBD) [11], plasma-assisted MOCVD [12], and SILAR method [13]. Among them, CBD is well known as a simple, most economical, and low-temperature technique for depositing large-area thin films of semiconductors. During the CBD process, the substrate is immersed in a solution containing a chalcogenide source $(\mathrm{X})$, a metal ion $(\mathrm{M}+)$, an added base, and a complexing agent. The process depends on the slow release of chalcogenide ions into an alkaline mixture where film formation on the substrate takes place when the ionic product (IP) exceeds the solubility product (SP) [14].

Large numbers of binary semiconductors compound like CdS [15-17], CdSe [18-20], $\mathrm{PbS}$ [21-23], CuS [24-26], and ZnS [27-29] can be deposited as thin films using CBD method. For the deposition of $\mathrm{ZnS}$ thin films via CBD, some factors should be considered and controlled. These factors include $\mathrm{Zn}$ precursor, S precursor, complexing agent, $\mathrm{pH}$ of the mixture, bath temperature, and deposition time [30-35].

In this paper, $\mathrm{ZnS}$ thin films are prepared by the chemical bath deposition technique. The prepared films were annealed at $100,150,200,250$, and $300{ }^{\circ} \mathrm{C}$. The effect of annealing temperatures on the structure and bandgap of the prepared films are investigated. 


\section{Materials and Methods}

ZnS thin films were synthesized on microscopic glass substrates (75 $\mathrm{mm} \times 25 \mathrm{~mm} \times 1 \mathrm{~mm}$ ). Figure 1 reveals the CBD setup used for this purpose.

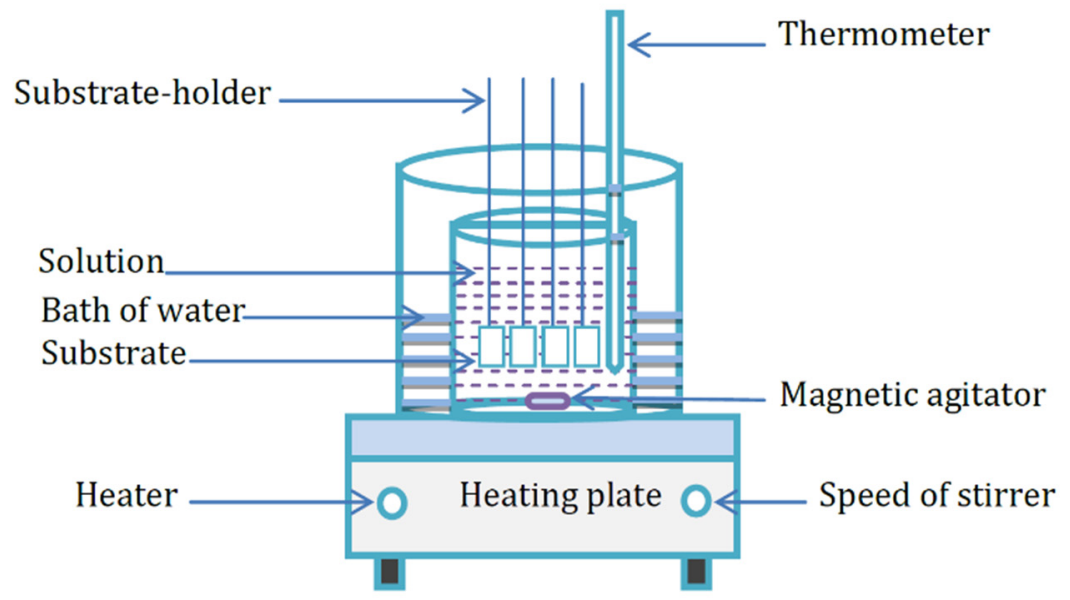

Figure 1. Chemical bath deposition system.

The glass substrates were cleaned carefully. They were first dipped into a chromic acid and set aside for $24 \mathrm{~h}$. Then, they were cleaned in distilled water with ultrasonic vibration for $15 \mathrm{~min}$, immersed into acetone, rinsed again with double distilled water. Finally, they were dried with air and kept in a desiccator [16].

$\mathrm{ZnS}$ thin films were prepared by immersing the substrate in a beaker containing the mixture of precursor materials $\left(0.03 \mathrm{M}\right.$ zinc sulfate heptahydrate $\left(\mathrm{ZnSO}_{4} \cdot 7 \mathrm{H}_{2} \mathrm{O}\right)$ as $\mathrm{Zn}^{2+}$ ion source, $0.5 \mathrm{M}$ thiourea as a source of $\mathrm{S}^{2-}\left(\mathrm{CS}\left(\mathrm{NH}_{2}\right)_{2}\right)$, and $2.5 \mathrm{M}$ of ammonia $\left(\mathrm{NH}_{4} \mathrm{OH}\right)$ as a complexing agent) at room temperature with continuous stirring and placed in a water bath $\left(\mathrm{T}_{\mathrm{b}} \pm 2\right)$. They were then heated to the needed deposition temperature of $\left(60^{\circ} \mathrm{C}\right)$. The $\mathrm{pH}$ was adjusted to be $(9.8 \pm 0.1)$ with continuous stirring. The substrates were then taken out after $45 \mathrm{~min}$ (deposition time) and washed with distilled water to remove the porous zinc-sulfide over the layer; then, they were left to be dried. Thin and uniform ZnS thin films have been obtained. An optical interferometer method $[25,36]$ was used to calculate their thickness.

The deposited films were then being annealed at 100, 150, 200, 250, and $300{ }^{\circ} \mathrm{C}$ for $60 \mathrm{~min}$ by a tube type of furnace. The structural and optical properties were then examined to determine the effect of annealing temperature on these characteristics. X-ray diffraction (XRD) spectra were recorded with an XPERT-PRO(X-Pert Pro PANalytical) diffractometer using $\mathrm{CuK} \alpha$ radiation $(\lambda=1.5406 \AA$, with $45 \mathrm{kV}$ and $40 \mathrm{~mA})$ for $2 \theta$ values over $20^{\circ}$ to $80^{\circ}$. The composition, morphology of the surface, along with the optical properties of the films, have also been characterized by an Energy-dispersive X-ray Spectroscopy (EDX, FEI Company, US), Field-emission scanning electron microscopy (FESEM) (450 Quanta, FEI Company, US), and the UV-VIS Spectrophotometer (6850 UV/Vis. SpectrophotometerJANEWAY, Cole-Parmer Ltd., Stone, Staffordshire, UK), respectively, in the wavelength range $190-1100 \mathrm{~nm}$.

\section{Results}

\subsection{Structure Analysis}

X-ray diffraction measurements have been carried out to study the structure of the as-deposited and annealed ZnS thin films. ZnS crystals typically exist in two phases: a cubic phase (zinc blende) that is stable at room temperature and a less dense hexagonal phase (wurtzite), which is stable at higher temperatures [37]. Annealing yields stress relief due to the readjust of $\mathrm{Zn}$ and $\mathrm{S}$ ions inside the $\mathrm{ZnS}$ lattice. Figure 2 shows the XRD pattern 
$\left(20^{\circ} \leq 2 \theta \leq 80^{\circ}\right)$ for the as-deposited and annealed at $300^{\circ} \mathrm{C}$ for one-hour $\mathrm{ZnS}$ thin films. It clearly gives a good indication of the polycrystalline structures of the obtained films.
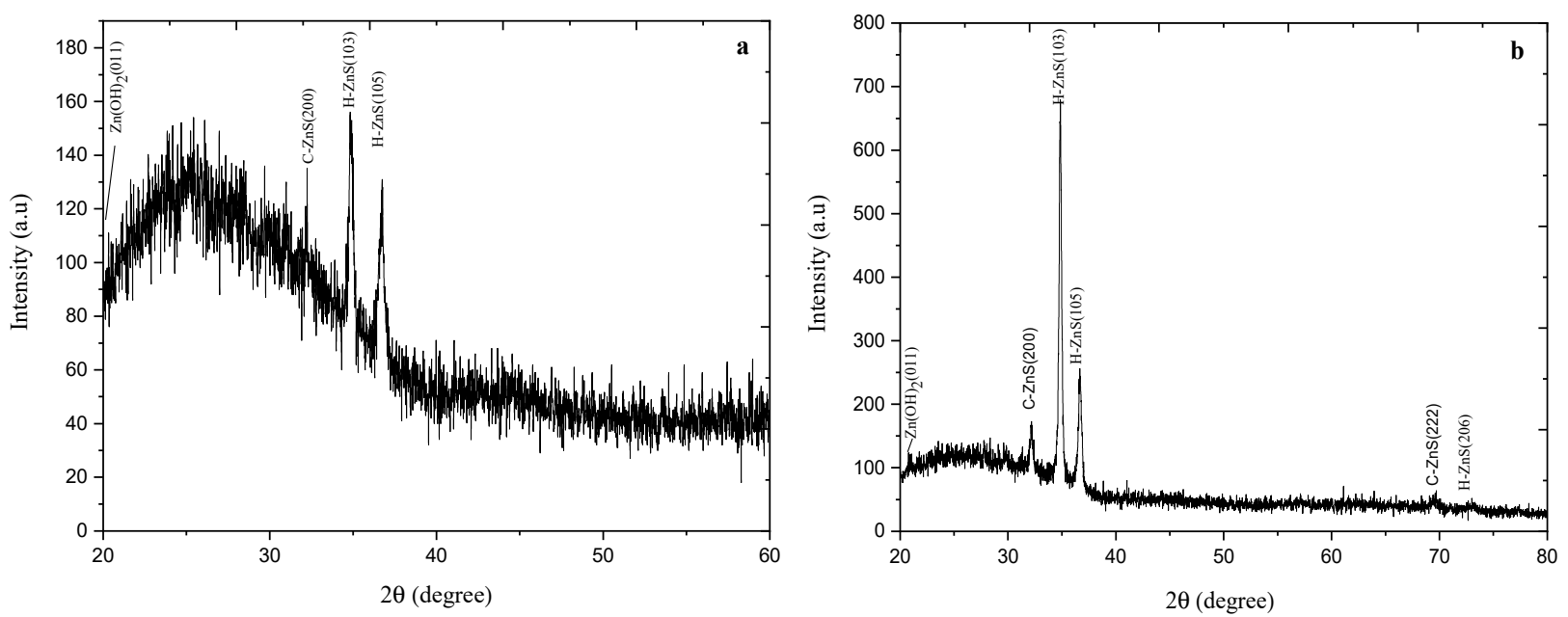

Figure 2. XRD pattern for as-deposited $\mathrm{ZnS}$ thin films (a), and (b) annealed $\mathrm{ZnS}$ thin films at $300{ }^{\circ} \mathrm{C}$ for one hour.

Figure 2 shows a demanding peak at $34.8^{\circ}$, which represents the preferential orientation of H-ZnS (103) films. The less intense XRD peaks at $36.68^{\circ}$ belong to the (H-105) lattice planes. A single diffraction peak was found in the XRD pattern as it is reflected from (200) direction and referred to the preferred orientation of cubic ZnS.

For the as-deposited $\mathrm{ZnS}$ films (Figure 2a), XRD pattern consists of $\mathrm{Zn}(\mathrm{OH})_{2}(011)$, $\mathrm{C}-\mathrm{ZnS}(200)$, and $\mathrm{H}-\mathrm{ZnS}$ (106). At the annealing temperature of $300^{\circ} \mathrm{C}$ (Figure $2 \mathrm{~b}$ ), the intensity peak of $\mathrm{Zn}(\mathrm{OH})_{2}(011), \mathrm{H}-\mathrm{ZnS}(105)$ and (106), and C-ZnS (200) just started to be more intensive and the intensity peak of both C-ZnS (222) and H-ZnS (206) appeared.

The speeds of hydrolysis of thiourea are found to be increased as the temperature increases. This increase promotes a moderately high grouping of $\mathrm{S}^{2-}$ particle and generally low fixation $\mathrm{OH}-$ particle. Here and now, the ionic product of $\mathrm{Zn}^{2+}$ and $\mathrm{S}^{2-}$ particles surpasses the solubility product of $\mathrm{ZnS}$, and then $\mathrm{ZnS}$ precipitation shapes in an arrangement. Unexpectedly, a low convergence of $\mathrm{OH}$ - particle is utilized to hydrolysis of thiourea and smothers the development of $\mathrm{Zn}(\mathrm{OH})_{2}$.

The lattice parameters a and $\mathrm{c}$ of the unit cell are given by the following equation $[38,39]$,

$$
\frac{1}{\mathrm{~d}^{2}}=\frac{4}{3} \frac{\mathrm{h}^{2}+\mathrm{hk}+\mathrm{k}^{2}}{\mathrm{a}^{2}}+\frac{\mathrm{l}^{2}}{\mathrm{c}^{2}}
$$

where $\mathrm{d}$ is the interplanar spacing.

The volume of the unit cell for hexagonal crystals is given by:

$$
\mathrm{V}=\mathrm{a}^{2} \mathrm{c} \sin (60)
$$

The grain size (D) values; are evaluated by Scherrer equation [40],

$$
\mathrm{D}=\frac{0.9 \lambda}{\beta \cos \theta}
$$

where $\lambda$ is the wavelength of X-ray (1.5406 $\AA$ ), $\beta$ is (FWHM) and $\theta$ is the Bragg angle.

In addition, grain size (D) values; are evaluated by the Williamson-Hall method [41]. These values are shown in Table 1. 
Table 1. Grain size (D) values of ZnS with a peak intensity of (103) plane using Scherrer equation and the Williamson-Hall method.

\begin{tabular}{|c|c|c|}
\hline Annealing Temperature $\left({ }^{\circ} \mathrm{C}\right)$ & $\begin{array}{c}\text { D } \\
\text { (A) }\end{array}$ & $\begin{array}{c}\text { D } \\
\text { (A) }\end{array}$ \\
\hline & Scherrer equation & Williamson-Hall method \\
\hline as-deposited & 352.52 & 322.97 \\
\hline 300 & 528.95 & 503.06 \\
\hline
\end{tabular}

Dislocation density has been estimated by [42],

$$
\delta=\frac{1}{\mathrm{D}^{2}}
$$

where $\delta$ also refers to as the measure of the amount of defects in a crystal.

The number of crystallites per unit area $(\mathrm{N})$ and the strain $(\varepsilon)$ of the films were calculated using the following formulae [42]:

$$
\begin{gathered}
N=\frac{t}{D^{3}} \\
\varepsilon=\frac{\beta \cos \theta}{4}
\end{gathered}
$$

where $t$ is the thickness of the thin films.

The Scherrer formula considers only the effect of crystallite size on the XRD peak broadening. However, it does not show anything about the microstructures of the lattice. Williamson-Hall (W-H) is the easier and simplified method. In this method, physical line broadening of X-ray diffraction peak occurs due to the size and micro strain of the crystals.

Table 2 shows the influence of annealing temperature on the structure of the deposited

\begin{tabular}{|c|c|c|c|c|c|c|c|c|c|c|}
\hline $\begin{array}{c}\text { Annealing } \\
\text { Temperature } \\
\left({ }^{\circ} \mathrm{C}\right)\end{array}$ & $\begin{array}{c}2 \theta \\
\text { (Degree) }\end{array}$ & $\beta$ & $\begin{array}{c}c \\
\text { (̊) }\end{array}$ & $\left.\begin{array}{c}\text { a } \\
(\AA ̊\end{array}\right)$ & $\begin{array}{c}\mathrm{D} \\
(\AA)\end{array}$ & $\begin{array}{l}\text { d } \\
(\AA)\end{array}$ & $\begin{array}{l}\text { V } \\
(\AA)^{3}\end{array}$ & $\begin{array}{c}\delta \\
\underset{\times 10^{-6}}{\left(\text { Lines } / \mathrm{m}^{2}\right)}\end{array}$ & $\begin{array}{c}\mathbf{N} \\
\times 10^{14}\end{array}$ & $\begin{array}{c}\mathcal{E} \\
\times 10^{-4}\end{array}$ \\
\hline as-deposited & 34.85 & 0.23 & 5.143 & 2.96 & 352.52 & 2.573 & 246.38 & 8.046 & 9.27 & 9 \\
\hline 300 & 34.82 & 0.157 & 5.148 & 2.972 & 528.95 & 2.576 & 247.08 & 3.574 & 8.55 & 6 \\
\hline
\end{tabular}
hexagonal ZnS with a peak intensity of preferential orientation (103).

Table 2. X-ray analysis of hexagonal ZnS with a peak intensity of (103) plane.

It is realized from Table 2 that since FWHM is reliant on the crystallite size and the lattice strain caused by the defect or dislocations, it decreases with the annealing as compared to the as-deposited thin film. The FWHM value decreased from $13.17^{\circ}$ for asdeposited films to $8.99^{\circ}$ for annealed films at $300^{\circ} \mathrm{C}$. In addition, as the grain size increases, lattice parameters (a and c), unit cell volume, dislocation density, the number of crystallites, and strain are all decreased with annealing at $300{ }^{\circ} \mathrm{C}$. Such results have already been apparent by others $[30,43]$. This means that the crystallinity of films is extremely affected by the annealing temperature. It also is consistent with the highest peak intensity seen from the XRD patterns.

Figure $3 \mathrm{a}, \mathrm{b}$ are SEM images of the as-deposited and annealed films at $\left(300^{\circ} \mathrm{C}\right) \mathrm{ZnS}$ thin films. 


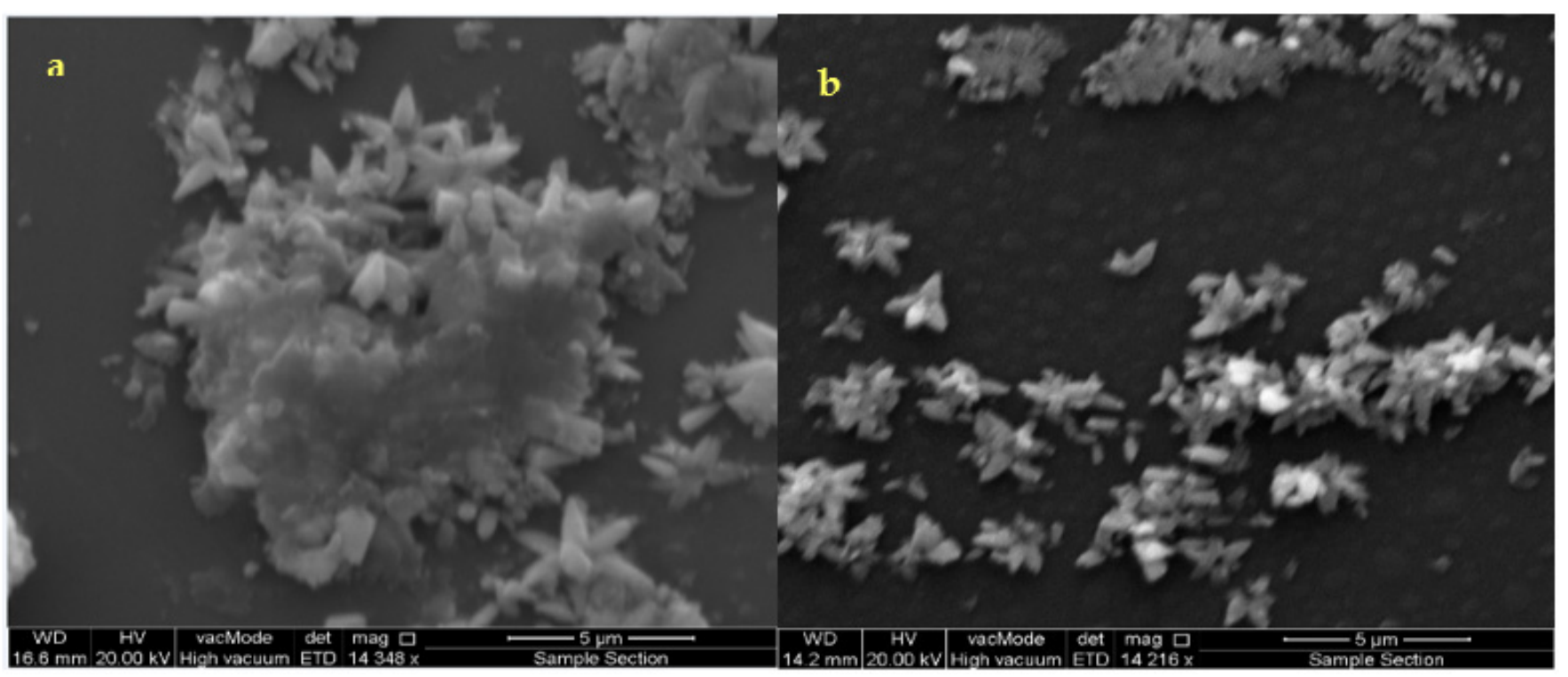

Figure 3. SEM microphotographs of the as-deposited $\mathrm{ZnS}$ thin film $(\mathbf{a}, \mathbf{b})$ annealed at $300{ }^{\circ} \mathrm{C}$.

(Figure 3a) shows the surfaces of the initial $\mathrm{ZnS}$ formation during the induction time, (i.e., at the start of deposition for as-deposited films). The as-deposited film has an inhomogeneous surface with some cracks and the reduced population of small grains on the surface of the substrate is detected. The surface morphologies of the grown ZnS films are shown in Figure $3 \mathrm{~b}$ after annealing to $300{ }^{\circ} \mathrm{C}$. It is progressively homogeneous and denser without any cracks. The grains are arbitrarily framed and medium in size. This gives the uniformity on the film surface to be observed. The growing process of the films is shown in Figure 3. It presents the formation of clusters on the surface, which is typical.

The clusters are formed by the aggregation of involved aqueous ions during the film deposition and growth. Using the same $\mathrm{Zn}(\mathrm{OH})_{4}^{2-} / \mathrm{HS}^{-}$concentration ratio, the desirable $\mathrm{pH}$ value achieved was found to be constant during the annealing process, i.e., a wellcontrolled chemical reaction maintained during deposition and growth of the ZnS films. Thus, it is suitable to adopt a clustering mechanism for the deposition and growth of the $\mathrm{ZnS}$ films under the chemical conditions imposed in this work. According to the estimated activation energy value at the initial $\mathrm{ZnS}$ film formation, there exists an intermediate adsorption process of the involved aqueous ions in the chemical solution/substrate surface, creating clusters and ZnS film during the induction time. During this growth process, the clusters of the involved ions may increase the adsorption progression resulting in heterogeneous catalysis in the chemical solution/substrate surface, which causes an increase of the thickness of the film in such a way where the film acts as a catalytic surface. Therefore, we believe that the growing process via clusters is controlled by the interaction of zinc hydroxide ions with the bisulfite ions in the frontier between the chemical solution/ZnS film and the substrate surface. Furthermore, it can be seen from Figure 3 that the deposited films show a flower-like structure. A better quality of the samples was obtained at the annealing temperature of $300^{\circ} \mathrm{C}$, though the oxidation process is blocked when the layer is annealed under the vacuum. The annealing process gives a chance to rearrange the atoms that make larger grain sizes and well-ordered primitive crystalline cells.

From Table 1 and correspondingly, with the analysis of the results XRD above (Figure 2), since the likelihood of oxidation increments at higher annealing temperature, it is essential to keep the annealing temperature in such ranges, where the crystallinity and transmittance are improved with no sorts of outer impacts.

The variation of chemical compositions of $\mathrm{Zn}$ and $\mathrm{S}$ was analyzed and evaluated by EDAX, as shown in Figure 4a,b. 

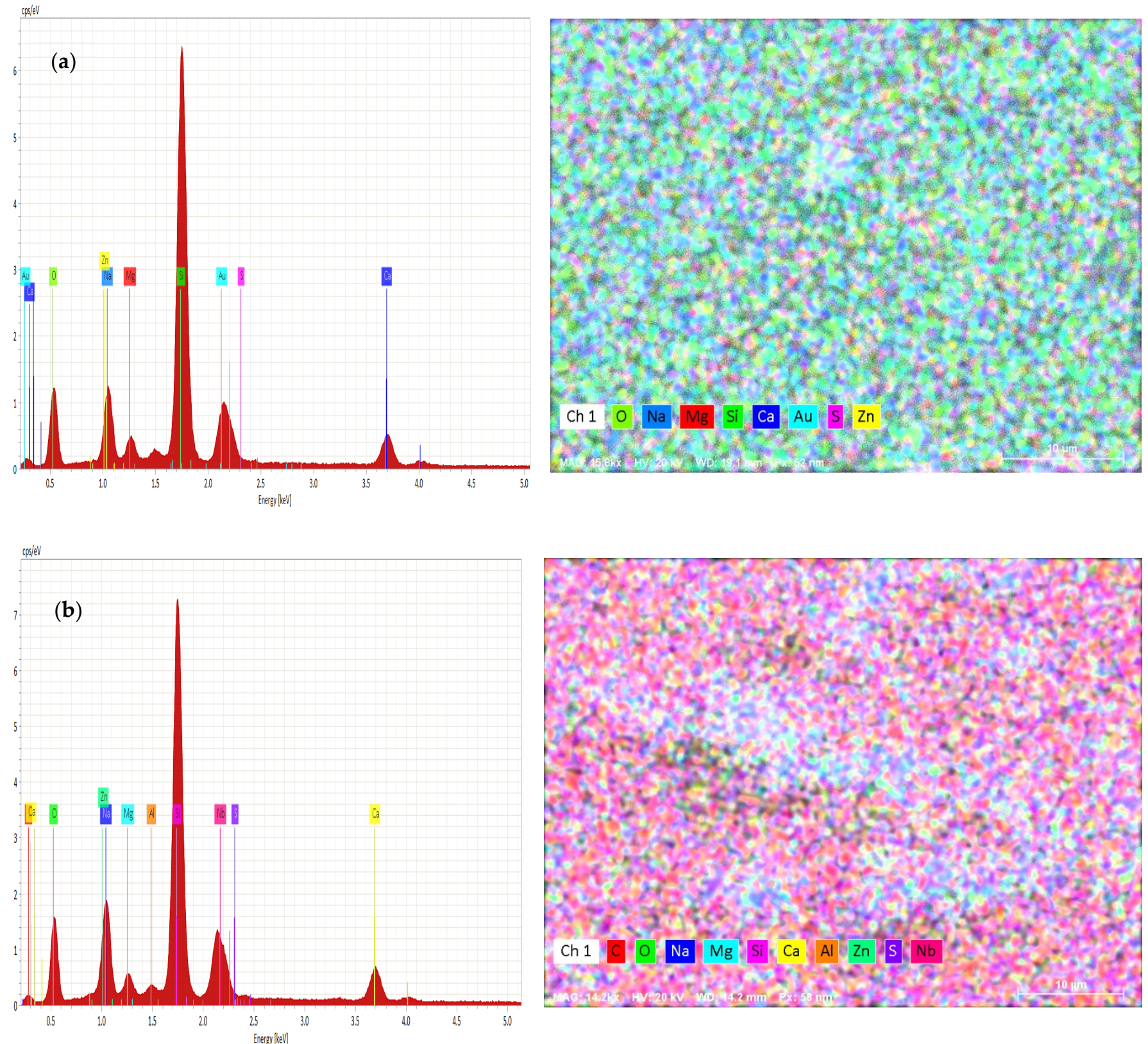

Figure 4. (a) EDAX of as-deposited ZnS thin films and (b) EDAX of ZnS thin films annealed at $300{ }^{\circ} \mathrm{C}$.

From Figure 4a,b, the EDAX analysis confirms the presence of zinc and sulfur in the obtained films. The annealed sample had more $\mathrm{Zn}$ content than $\mathrm{S}$. In addition, oxygen contents were increased with the annealing temperature of $300{ }^{\circ} \mathrm{C}$. The annealing of the samples caused a decrease in the concentration of $S$ atoms. An excess of $Z n$ may be due to the amount of $\mathrm{Zn}(\mathrm{OH})_{2}$ or $\mathrm{ZnO}$ originating from the alkaline reaction solution.

\subsection{Optical Analysis}

Optical characteristics were examined by measuring the transmittance and absorbance at the range of 310-1100 $\mathrm{nm}$ for the as-deposited and annealed $\mathrm{ZnS}$ films.

Figure 5 shows the absorption spectra of as-deposited $\mathrm{ZnS}$ thin films and annealed at temperatures of $100,150,200,250$, and $300^{\circ} \mathrm{C}$. 


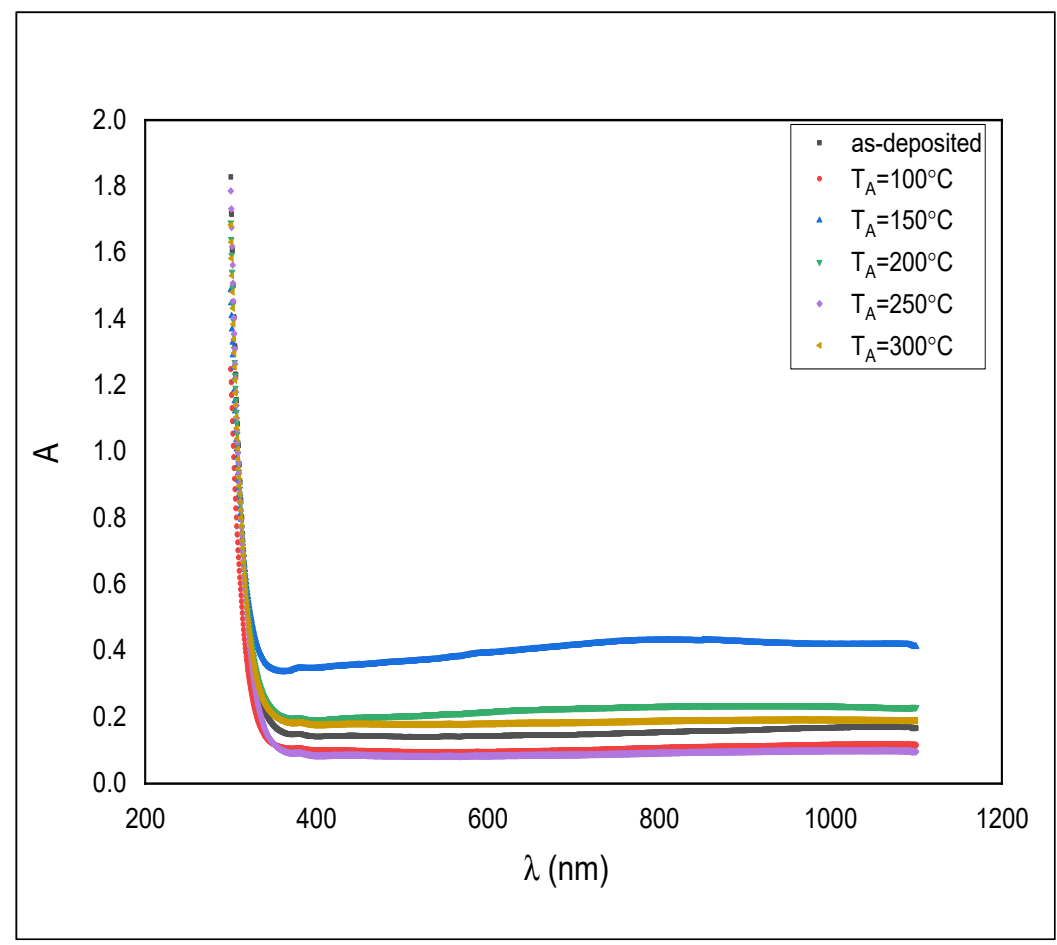

Figure 5. Absorbance spectra for the as-deposited and annealed ZnS films.

All samples displayed higher absorbance in the UV region rather than near the IR region. The absorbance is just somewhat in the visible region. That makes the material beneficial as a windscreen covering and driving mirror to forestall the impact of striking light into a driver's eyes from an approaching vehicle and following vehicle.

The transmittance measurements of the films were done using UV/VIS spectrophotometer and are shown in Figure 6.

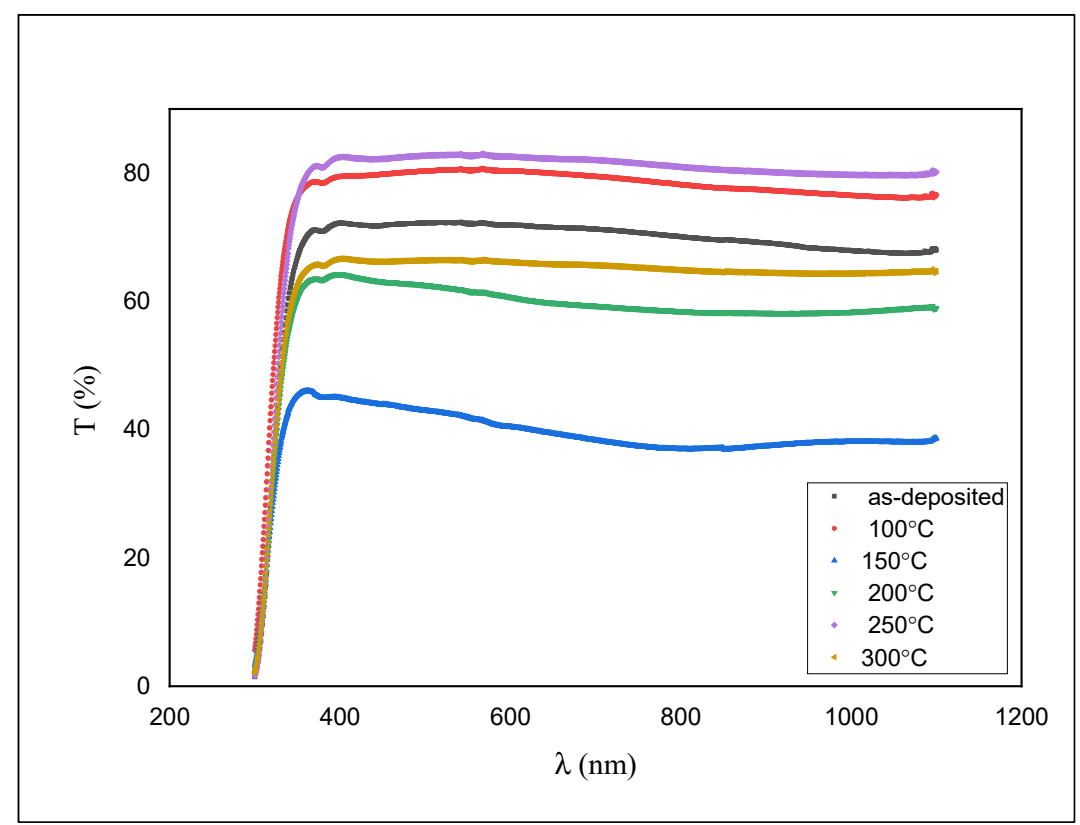

Figure 6. Transmission spectra for as-deposited and annealed ZnS films.

As shown in Figure 6, the transmission is around $76 \%$ for the as-deposited film and diminished to $\sim 50 \%$ with an expansion in the annealing temperature. 
To calculate the optical energy gap, a plot of $(\alpha \mathrm{h} v)^{2}$ versus $\mathrm{h} v$ (where $\alpha$ is the optical absorption coefficient and $\mathrm{h} v$ is the energy of the incident photon) was made as shown in Figure 7.

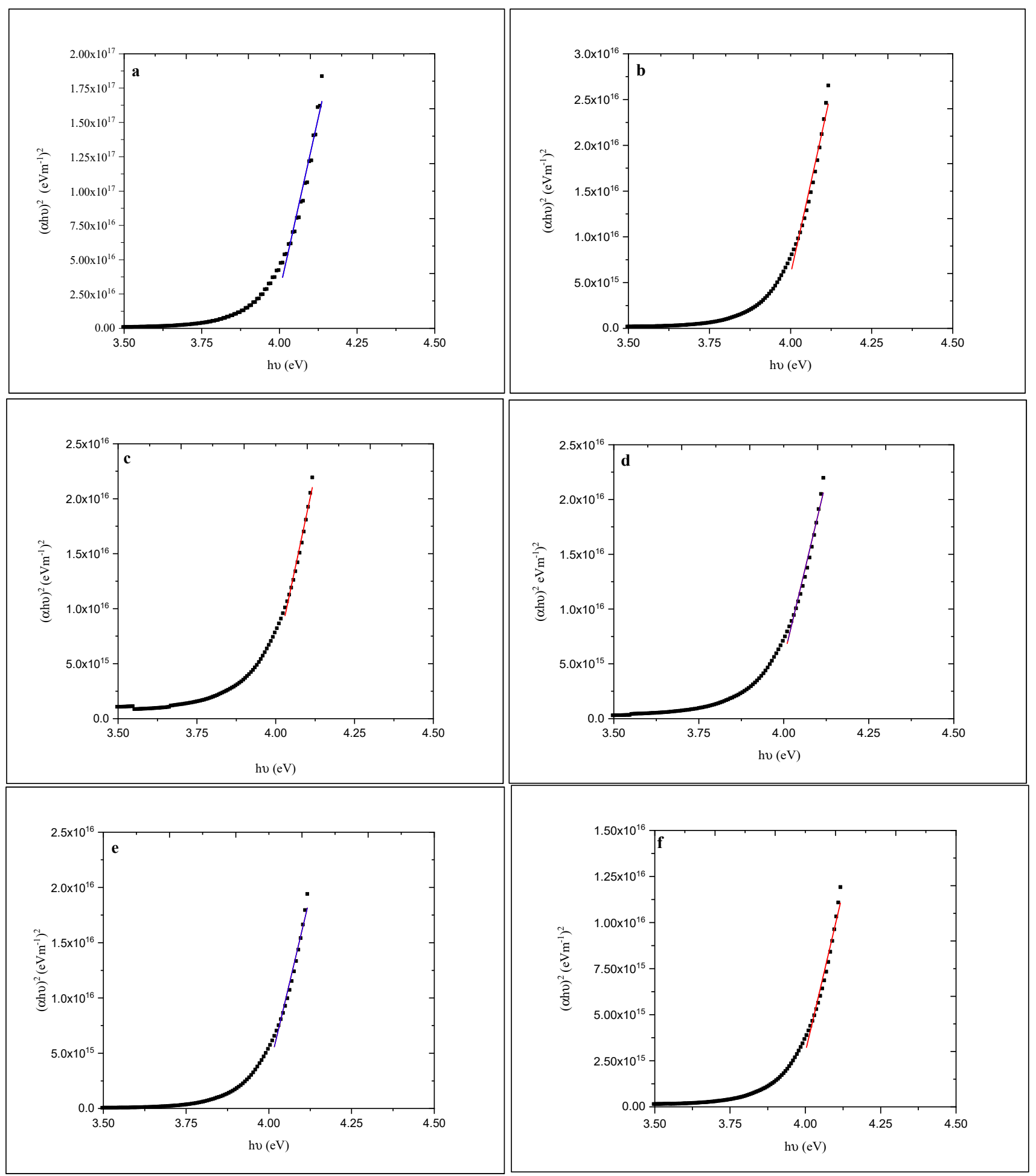

Figure 7. Plots of $(\alpha \mathrm{hv})^{2}$ versus hv for (a)-as-deposited and annealed (at (b) 100, (c) 150, (d) 200, (e) 250, and (f) $\left.300{ }^{\circ} \mathrm{C}\right)$ ZnS films.

The energy gap (Eg) was determined using the relationship [44]:

$$
\alpha h v=K(h v-E g)^{1 / 2}
$$


where $\mathrm{K}$ is a constant.

The calculated Eg and thickness values for both as-deposited and annealed films are shown in Figure 8.

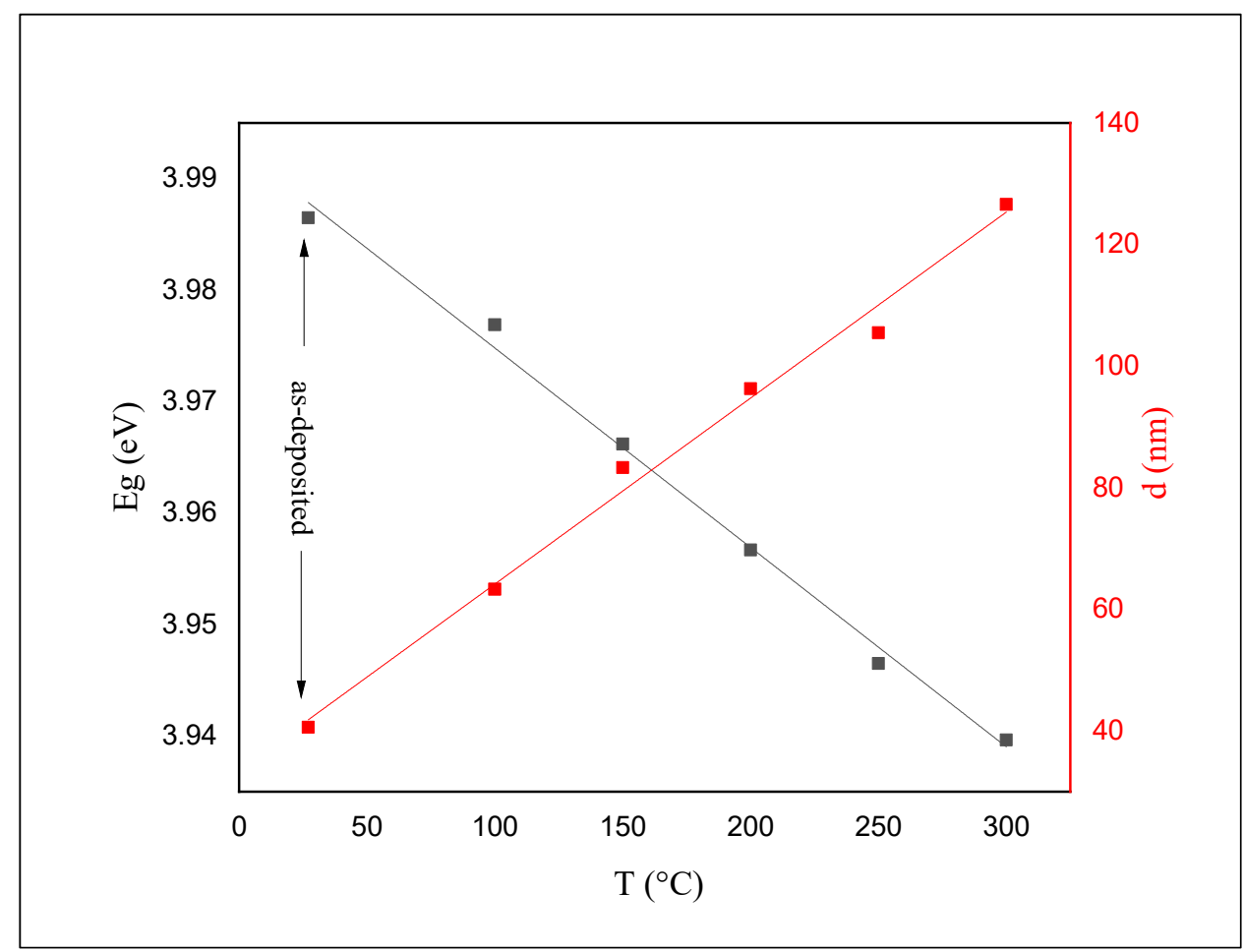

Figure 8. Energy gap and thickness for as-deposited and annealed $\mathrm{ZnS}$ thin films as a function of annealing temperature.

The value of Eg for the as-deposited $\mathrm{ZnS}$ films was calculated to be $3.98 \mathrm{eV}$. This value has been reduced to $3.93 \mathrm{eV}$ after annealing. The color of the as-deposited films was white before and after annealing. The absorption edge shifts gradually toward longer wavelengths and shrinks the bandgap (see Figures 6 and 7) as the annealing temperature increases.

\section{Conclusions}

ZnS thin films were prepared using the chemical bath deposition technique. The structural properties for as-deposited and annealed films at $300{ }^{\circ} \mathrm{C}$ were examined. In addition, the optical properties for as-deposited and annealed films at 100, 150, 200, 250, and $300{ }^{\circ} \mathrm{C}$ were also investigated. XRD analysis shows the polycrystalline structures of the grown films. It was found that the FWHM is dependent on the crystallite size and the lattice strain caused by the defect or dislocations. The FWHM had been reduced with annealing. Correspondingly, SEM images of the annealed ZnS films were shown to be moderately denser and more homogeneous without any cracks. However, relatively small-sized grains were randomly formed, and the as-deposited film had seen to have an inhomogeneous surface with some cracks. Other than that, the annealed samples were observed to have more $\mathrm{Zn}$ content than $\mathrm{S}$. The $\mathrm{Zn} / \mathrm{S}$ proportion had been diminished gradually with annealing. The optical characterization reveals that the transmittance was around $76 \%$ of the as-deposited film and decreased to $~ 50 \%$ with the increasing of annealing temperature. The bandgap energy of the as-deposited film was $3.98 \mathrm{eV}$ and was found to be decreased to $3.93 \mathrm{eV}$ after annealing. In addition, the white color of the as-deposited thin films did not change after annealing.

Funding: This work was sponsored by the Department of Physics, College of Science, University of Duhok. This research received no external funding. 
Institutional Review Board Statement: Not applicable.

Informed Consent Statement: Not applicable.

Data Availability Statement: Not applicable.

Acknowledgments: The authors would like to acknowledge the Department of Physics, College of Science, University of Duhok.

Conflicts of Interest: The authors declare no conflict of interest.

\section{References}

1. Amrollahi Bioki, H.; Borhani Zarandi, M. Effects of annealing and thickness on the structural and optical properties of crystalline ZnS thin films prepared by PVD method. Int. J. Opt. Photonics 2011, 5, 121-128.

2. Chen, R.F.; Yu, J.; Hua, Y.Q.; Xu, R.L.; Liu, H.X. Study of structure and optical properties of magnetron sputtered ZnS thin films by annealing. Appl. Mech. Mater. 2012, 130-134, 1379-1382. [CrossRef]

3. Bacha, K.B.; Bitri, N.; Bouzouita, H. Effect of annealing parameters on structural and morphological properties of sprayed ZnS thin films. Optik 2016, 127, 3100-3104. [CrossRef]

4. Khanegahi, B.; Sedghi, H. Effect of Annealing Temperature on Optical Properties of ZnS Thin Films Studied by Spectroscopic Ellipsometry Analysis Method. Int. J. Nano Rech. 2018, 1, 12-17.

5. Lu, L.; Xu, Z.; Zhang, F.; Zhao, S.; Wang, L.; Zhuo, Z.; Song, D.; Zhu, H.; Wang, Y. Using ZnS nanostructured thin films to enhance light extraction from organic light-emitting diodes. Energy Fuels 2010, 24, 3743-3747. [CrossRef]

6. Tong, W.; Tran, T.K.; Park, W.; Schon, S.; Wagner, B.K.; Summers, C.J. High-quality ZnS thin-film growth for flat-panel displays. Journal of the Society for Information Display. J. Soc. Inf. Disp. 1996, 4, 325-329. [CrossRef]

7. Qiu, K.; Qiu, D.; Cai, L.; Li, S.; Wu, W.; Liang, Z.; Shen, H. Preparation of ZnS thin films and ZnS/p-Si heterojunction solar cells. Mater. Lett. 2017, 198, 23-26. [CrossRef]

8. Tran, N.; Lamb, R.; Mar, G. Single source chemical vapour deposition of zinc sulphide thin films: Film composition and structure. Colloids Surf. A Physicochem. Eng. Asp. 1999, 155, 93-100. [CrossRef]

9. Djelloul, A.; Adnane, M.; Larbah, Y.; Sahraoui, T.; Zegadi, C.; Maha, A.; Rahal, B. Properties Study of ZnS Thin Films Prepared by Spray Pyrolysis Method. J. Nano-Electron. Phys. 2015, 7, 04045.

10. Haque, F.; Rahman, K.S.; Islam, M.A.; Rashid, M.J.; Akhtaruzzaman, M.; Alam, M.M.; Alothman, Z.A.; Sopian, K.; Amin, N. Growth optimization of $\mathrm{ZnS}$ thin films by RF magnetron sputtering as prospective buffer layer in thin film solar cells. Chalcogenide Lett. 2014, 11, 189-197.

11. Oliva, A.I.; González-Chan, I.; Rejón, V.; Rojas, J.; Patiño, R.; Aguilar, D. Chemical bath method for ZnS thin films preparation. In Proceedings of the 2010 7th International Conference on Electrical Engineering Computing Science and Automatic Control, Tuxtla Gutierrez, Mexico, 8-10 September 2010; IEEE: Piscataway, NJ, USA, 2010.

12. Zhang, Z.; Shen, D.; Zhang, J.; Shan, C.; Lu, Y.; Liu, Y.; Li, B.; Zhao, D.; Yao, B.; Fan, X. The growth of single cubic phase ZnS thin films on silica glass by plasma-assisted metalorganic chemical vapor deposition. Thin Solid Films 2006, 513, 114-117. [CrossRef]

13. Ashith, V.; Rao, K.G. Structural and optical properties of ZnS thin films by SILAR technique obtained by acetate precursor. IOP Conf. Ser. Mater. Sci. Eng. 2018, 360, 012058. [CrossRef]

14. Allouche, N.K.; Ben Nasr, T.; Guasch, C.; Turki, N.K. Optimization of the synthesis and characterizations of chemical bath deposited Cu2S thin films. Comptes Rendus Chim. 2010, 13, 1364-1369. [CrossRef]

15. Feitosa, A.; Miranda, M.A.R.; Sasaki, J.M.; Araújo-Silva, M.A. A new route for preparing CdS thin films by chemical bath deposition using EDTA as ligand. Braz. J. Phys. 2004, 34, 656-658. [CrossRef]

16. Mohammed, R.Y.; Ilyas, B.M. Comparative study of chemically deposited CdS thin films and of the non-synthesized CdSO 4 under pressure and temperature within first principles. Mater. Today Commun. 2020, 25, 101518. [CrossRef]

17. Mohammed, R.Y.; Abduol, S.; Mousa, A.M. Structural and optical properties of chemically deposited CdS thin films. Int. Lett. Chem. Phys. Astron. 2014, 10, 91-104. [CrossRef]

18. VanderHyde, C.A.; Sartale, S.; Patil, J.M.; Ghoderao, K.P.; Sawant, J.P.; Kale, R.B. Room temperature chemical bath deposition of cadmium selenide, cadmium sulfide and cadmium sulfoselenide thin films with novel nanostructures. Solid State Sci. 2015, 48, 186-192. [CrossRef]

19. Ahmed, S.M.; Mohammed, R.Y.; Yousif, S.O. Investigation the effect of annealing temperature on the optical properties of CdSe thin films. Rev. Innovaciencia 2018, 6, 1-6. [CrossRef]

20. Kariper, I.; Bağlayan, O.; Gode, F. Fabrication and optical characterization of CdSe thin films grown by chemical bath deposition. Acta Phys. Pol. A 2015, 128, B-219. [CrossRef]

21. Abdallah, B.; Hussein, R.; Al-Kafri, N.; Zetoun, W. PbS thin films prepared by chemical bath deposition: Effects of concentration on the morphology, structure and optical properties. Iran. J. Sci. Technol. Trans. A Sci. 2019, 43, 1371-1380. [CrossRef]

22. Rajathi, S.; Kirubavathi, K.; Selvaraju, K. Structural, morphological, optical, and photoluminescence properties of nanocrystalline $\mathrm{PbS}$ thin films grown by chemical bath deposition. Arab. J. Chem. 2017, 10, 1167-1174. [CrossRef]

23. Seghaier, S.; Kirubavathi, K.; Selvaraju, K. Structural and optical properties of PbS thin films deposited by chemical bath deposition. Mater. Chem. Phys. 2006, 97, 71-80. [CrossRef] 
24. Chaki, S.H.; Deshpande, M.; Tailor, J.P. Characterization of CuS nanocrystalline thin films synthesized by chemical bath deposition and dip coating techniques. Thin Solid Film 2014, 550, 291-297. [CrossRef]

25. Mohammed, K.A.; Ahmed, S.M.; Mohammed, R.Y. Investigation of Structure, Optical, and Electrical Properties of CuS Thin Films by CBD Technique. Crystals 2020, 10, 684. [CrossRef]

26. Kassim, A.; Min, H.S.; Haron, M.J.; Nagalingam, S. Preparation of thin films of copper sulfide by chemical bath deposition. Int. J. Pharm. Life Sci. 2011, 2, 190-1194.

27. Khalil, M.H.; Mohammed, R.Y.; Ibrahem, M.A. The Influence of CBD Parameters on the Energy Gap of ZnS Narcissus-Like Nanostructured Thin Films. Coatings 2021, 11, 1131. [CrossRef]

28. Cheng, J.; Fan, D.; Wang, H.; Liu, B.; Zhang, Y.; Yan, H. Chemical bath deposition of crystalline ZnS thin films. Semicond. Sci. Technol. 2003, 18, 676. [CrossRef]

29. Rosado-Mendoza, M.; Oliva, A. Chemical bath deposition of zinc sulfide films doped with copper. Mater. Manuf. Process. 2016, 31, 1454-1460. [CrossRef]

30. Ali, M.M. Effect of annealing temperature on the structural and optical properties of ZnS thin films deposited by CBD. Basrah J. Sci. 2015, 33, 156-181.

31. Nasr, T.B.; Kamoun, N.; Kanzari, M.; Bennaceur, R. Effect of $\mathrm{pH}$ on the properties of ZnS thin films grown by chemical bath deposition. Thin Solid Film 2006, 500, 4-8. [CrossRef]

32. Zein, R.; Alghoraibi, I. Influence of bath temperature and deposition time on topographical and optical properties of nanoparticles ZnS thin films synthesized by a chemical bath deposition method. J. Nanomater. 2019, 2019, 1-13. [CrossRef]

33. Babatunde, R.; Bolanle, Y.; Adegboyo, O. Effects of deposition time of ZnS thin film on optical and morphological properties of ZnS deposited by chemical bath deposition method for photovoltaic application. J. Theor. Appl. Phys. 2019, 1, 38-45.

34. Abel, S.; Tesfaye, J.L.; Kiran, R.; Deepak, T.; Ruby, A.U.; Venkatesh, S.; Krishnaraj, R. Studying the Effect of Metallic Precursor Concentration on the Structural, Optical, and Morphological Properties of Zinc Sulfide Thin Films in Photovoltaic Cell Applications. Adv. Mater. Sci. Eng. 2021, 2021, 7443664. [CrossRef]

35. Liu, J.; Wei, A.; Zhao, Y. Effect of different complexing agents on the properties of chemical-bath-deposited ZnS thin films. J. Alloy. Compd. 2014, 588, 228-234. [CrossRef]

36. Abdulla, M.M.; Hasan, N.H.; Mohammed, H.I.; Mohamed, G.H.; Al-Hamdani, K.A.; Abdulameer, A.F. Investigation of optical properties of the PbS/CdS thin films by thermal evaporation. J. Electron Devices 2012, 12, 761-766.

37. Berger, L.I. Semiconductor Materials; CRC Press: Boca Raton, FL, USA, 1996.

38. Goswami, A. Thin Film Fundamentals; New Age International (P) Limited Publisher: New Delhi, India, 1996.

39. German, R.M.; Park, S.J. Handbook of Mathematical Relations in Particulate Materials Processing: Ceramics, Powder Metals, Cermets, Carbides, Hard Materials, and Minerals; John Wiley \& Sons: Hoboken, NJ, USA, 2009; Volume 3.

40. Koch, C.C.; Ovid'Ko, I.A.; Seal, S.; Veprek, S. Structural Nanocrystalline Materials: Fundamentals and Applications; Cambridge University Press: Cambridge, UK, 2007.

41. Nath, D.; Singh, F.; Das, R. X-ray diffraction analysis by Williamson-Hall, Halder-Wagner and size-strain plot methods of CdSe nanoparticles-a comparative study. Mater. Chem. Phys. 2020, 239, 122021. [CrossRef]

42. Kathirvel, P.; Manoharan, D.; Mohan, S.M.; Kumar, S. Spectral investigations of chemical bath deposited zinc oxide thin films-ammonia gas sensor. J. Optoelectron. Biomed. Mater. 2009, 1, 25-33.

43. Eid, A.; Salim, S.M.; Sedik, M.B.; Omar, H.; Dahy, T.; Abou-Elkhair, H.M. Preparation and Characterization of ZnS thin films. J. Appl. Sci. Res. 2010, 6, 777-784.

44. Makuła, P.; Pacia, M.; Macyk, W. How to correctly determine the band gap energy of modified semiconductor photocatalysts based on UV-Vis spectra. J. Phys. Chem. Lett. 2018, 9, 6814-6817. [CrossRef] 